\title{
Beyond the Bioceanic Route: indigenous crafts and the potential of ethno-tourism in the southwest of Mato Grosso do Sul
}

\author{
Para além da Rota Bioceânica: o artesanato indígena e o potencial do \\ etnoturismo no sudoeste de Mato Grosso do Sul

\section{Más allá de la Ruta Bioceánica: la artesanía indígena y el potencial del etnoturismo en el sudoeste de Mato Grosso do Sul}

\author{
Gilberto Luiz Alves ${ }^{1}$ \\ Fábio Luciano Violin² \\ Maristela Benites ${ }^{3}$ \\ Received on 28 June 2021; revised and approved on 28 Sept. 2021; accepted on 13 Oct. 2021 \\ DOI: http://dx.doi.org/10.20435/inter.v22i4.3417
}

\begin{abstract}
The object of this article is the relationship between indigenous crafts and the potential of ethno-tourism in the southwest of Mato Grosso do Sul. With the implementation of the Bi-oceanic Route, government propaganda has been promising that this economic corridor will stimulate tourism, hence the objective of probing the potential of ethno-tourism in that region, which will directly suffer a great impact as a result of this large-scale undertaking. The theoretical-methodological framework is based on the basic assumption that human productions necessarily result from work, hence the need to treat them as social relations. Therefore, the object of research only acquires understanding within the most general frameworks of capitalist society, expressed by categories such as capital, labor, labor force, market, merchandise, among others. Regarding the methodology, the empirical data survey looked for primary sources of a documentary and imaginary nature, especially photographs. Systematic observations were also recovered in work siltation, carried out both in production and commercialization stations of indigenous artifacts. Secondary sources relevant to the object were also raised, such as catalogs, scientific articles, master's dissertations, doctoral theses, books, and book chapters. To make ethno-tourism viable, the general conclusion is that it invests in a set of initiatives, planned in an integrated and continuous manner within a permanent project. In this group, the improvement of ethnic artifacts is urgent; the recovery and systematic maintenance of the access roads to indigenous lands, as well as the restoration and adaptation of the buildings already available in the villages, with a view to adapting them to the provision of services and products to tourists.
\end{abstract}

Keywords: environment; cultural practices; crafts; tourism.

Resumo: O objeto deste artigo é a relação entre o artesanato indígena e o potencial etnoturístico no Sudoeste de Mato Grosso do Sul. Com a implantação da Rota Bioceânica, a propaganda governamental vem prometendo que esse corredor econômico irá estimular o turismo, daí o objetivo de sondar o potencial do etnoturismo na referida região, que sofrerá diretamente grande impacto em decorrência desse megaempreendimento. O referencial teórico-metodológico parte do pressuposto básico de que as produções humanas decorrem, necessariamente, do trabalho, daí a necessidade de tratá-las como relações sociais. Portanto, o objeto de investigação só ganha compreensão dentro dos marcos mais gerais da sociedade capitalista, expressos por categorias como capital, trabalho, força de trabalho, mercado, mercadoria, entre outras. Em relação à metodologia, o levantamento de dados empíricos buscou fontes primárias de natureza documental e imagética, em especial fotografias. Também foram recuperadas observações sistemáticas em situação de trabalho, realizadas tanto em postos de produção quanto de comercialização de artefatos indígenas. Ainda foram levantadas fontes secundárias pertinentes ao objeto, tais como catálogos, artigos científicos, dissertações de mestrado, teses de doutorado, livros e capítulos de livros. Para viabilizar o etnoturismo, a conclusão geral é a de que haja investimento num conjunto de iniciativas, pleiteado de forma integrada e contínua dentro de projeto de natureza permanente. Nesse conjunto, se fazem urgentes o aprimoramento dos artefatos étnicos; a recuperação e manutenção sistemática de estradas que dão acesso às terras indígenas,

\footnotetext{
${ }^{1}$ Anhanguera-Uniderp University, Campo Grande, Mato Grosso do Sul, Brasil.

2 São Paulo State University (UNESP), Rosana, São Paulo, Brasil.

${ }^{3}$ Federal University of Mato Grosso do Sul (UFMS), Campo Grande, Mato Grosso do Sul, Brasil.
} 
bem como a restauração, recuperação e adaptação de edificações já disponíveis nas aldeias visando adequá-las à oferta de serviços e produtos aos turistas.

Palavras-chave: turismo; práticas culturais; artesanato; ambiente.

Resumen: El objeto de este artículo es la relación entre la artesanía indígena y el potencial del etnoturismo en el suroeste de Mato Grosso do Sul. Con la implementación de la Ruta Bioceánica, la propaganda gubernamental ha venido prometiendo que este corredor económico estimulará el turismo, de ahí el objetivo de sondear el potencial del etnoturismo en esa región que sufrirá directamente un gran impacto como resultado de este emprendimiento a gran escala. El marco teórico-metodológico se basa en el supuesto básico de que las producciones humanas necesariamente resultan del trabajo, de ahí la necesidad de tratarlas como relaciones sociales. Por lo tanto, el objeto de investigación solo adquiere comprensión dentro de los marcos más generales de la sociedad capitalista, expresados por categorías como capital, trabajo, fuerza de trabajo, mercado, mercancías, entre otras. En cuanto a la metodología, el relevamiento de datos empíricos buscó fuentes primarias de carácter documental e imaginario, especialmente fotografías. También se recuperaron observaciones sistemáticas en situaciones de trabajo, realizadas tanto en estaciones de producción como de comercialización de artefactos indígenas. También se plantearon fuentes secundarias relevantes para el objeto, como catálogos, artículos científicos, disertaciones de maestría, tesis doctorales, libros y capítulos de libros. Para viabilizar el etnoturismo, la conclusión general es que se invierte en un conjunto de iniciativas, planteadas de manera integrada y continua dentro de un proyecto de carácter permanente. En este conjunto, la mejora de los artefactos étnicos es urgente; la recuperación y mantenimiento sistemático de las vías de acceso a las tierras indígenas, así como la restauración y adecuación de las edificaciones ya disponibles en las aldeas, con miras a adecuarlas a la prestación de servicios y productos al turista.

Palabras claves: turismo; prácticas culturales; artesanía; medio ambiente.

\section{INTRODUCTION}

The object of this article is the relationship between indigenous handicrafts and the ethnotourism potential in the Southwest of Mato Grosso do Sul, a region that will be deeply impacted by the Bioceanic Route or Route of Latin American Integration. This freight transport corridor will link the Atlantic Ocean to the Pacific Ocean, cutting through the heart of South America. In the discourse of government instances, at all levels, optimism is dominant. He promises that the route will generate an influx of development throughout its trajectory, opening up new opportunities for economic exploitation of local wealth, intensifying tourism, generating jobs and raising the quality of life of the inhabitants in its surroundings.

As one of the promises of government propaganda is that this economic corridor will stimulate tourism, the objective of this paper is to discuss aspects related to the ethno-tourism potential of the Southwest of Mato Grosso do Sul and the role reserved for indigenous handicrafts in the sense of realizing it. As it is understood as an economic activity that explores the cultural practices of a particular ethnicity in order to make them attractive to visitors (NOGUEIRA et al., 2013), it is correct to state that there is potential for ethnotourism in the region. But the conditions to be met to make its realization viable need to be explained. One of them, for example, is the ability of local producers to offer products. The strength of indigenous crafts is used to exemplify it. But it's not enough, it's just one of those conditions. Regarding the relevance of the objective, it should be said that the State of Mato Grosso do Sul has the second-largest indigenous population among all federated units in Brazil and that a significant part is concentrated in the region in question.

Regarding the methodology, it should be emphasized that the survey of empirical data sought primary sources of a documentary and imagery nature, especially photographs. Systematic observations in work siltation were also retrieved, carried out both in production and commercialization posts of indigenous artifacts, during the execution of the research project 
Indigenous Crafts, Technological Changes and Innovations in Mato Grosso do Sul. Secondary sources relevant to the object were also raised, such as catalogs, scientific articles, master's theses, doctoral theses, books, and book chapters.

The theoretical-methodological framework adopted as a basic presupposition the fact that all human productions necessarily result from work. This means that the products of human labor must be treated as social relations. Therefore, the object of investigation only gains understanding within the most general frameworks of capitalist society. In other words, studies on cultural practices such as crafts cannot be carried out as if internal laws explained them. The movement of capitalist society is what gives them meaning and substance, hence the need for prior apprehension of these laws that govern their movement and are expressed in categories such as capital, merchandise, labor power, use value, exchange value, surplus value and accumulation, among the most important (ALVES, 2001).

\section{THE BIOCEANIC ROUTE AND THE REDESIGN OF INTERNATIONAL ECONOMIC RELATIONS}

China's economic development has reshaped international economic relations at the beginning of the 21st century. The portentous Chinese demand for food has been a providential lever for the export of Brazilian commodities. Agribusiness is sailing at full speed in these favorable winds. Among the initiatives to increase the meeting of needs posed by this situation is the Bioceanic Route or Route of Latin American Integration.

The implementation of this onshore export corridor towards Asia has shaken expectations in the Southwest of Mato Grosso do Sul, a region historically relegated to the background in regional development proposals. In Argentina, Brazil, and Paraguay the projects started to come out of the paper. Asphalt coating of highways, development of port infrastructure, international bridge over the Paraguay River, connecting Porto Murtinho, in Brazil, to Carmelo Peralta, in Paraguay, are some of the initiatives that are already visible (Figure 1 ).

Figure 1 - Bioceanic Route

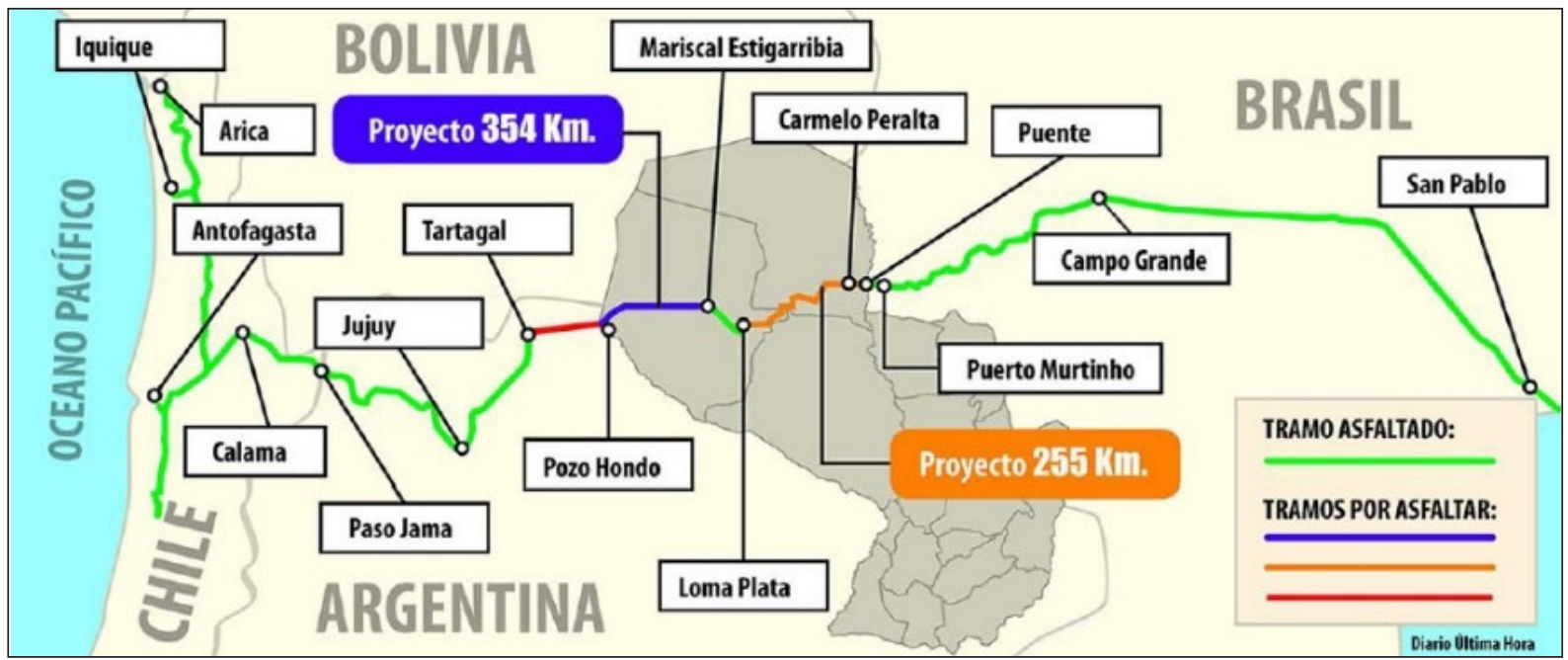

Source: PIMENTA, 2019. 
The land transport corridor, with an approximate length of 3450 kilometers, will cut through South America and connect the Atlantic and Pacific oceans, having as extreme points the ports of Santos and Paranaguá, in Brazil, and lquique and Antofogasta, in Chile. This highway will reduce the length of the route and the freight cost for goods to be transported to Asia. The governor of Mato Grosso do Sul, Reinaldo Azambuja, representative of agribusiness in the state, has made use of these two aspects in his apology for the route. It has been stressing that the distance between the production areas and the destination of the goods will be shortened by around eight thousand kilometers and the travel time will be reduced by around 17 days. On the shipping freight of the products, it foresees a reduction between $25 \%$ and $50 \%$ of the rates currently practiced (ANELO [SBT MS], 2021).

As usual in mega ventures that periodically shake up "nuestra América", government officials at all levels are keen to use an optimistic chant to convince everyone that the environmental impacts of this corridor will be negligible; that all the regions crossed will benefit from the attraction of new ventures, and that tourism will provide a healthy opportunity to attract foreign exchange. These changes would also converge to the emergence of new work alternatives to alleviate unemployment and raise the income and quality of life of the workforce at local levels. Finally, always finally, the speech also promises a vague "cultural opening" in the extensive territory crossed by the road corridor. This is what has been announced, for example, by career diplomat João Carlos Parkinson, from the Ministry of Foreign Affairs (PORTAL VGV, 2020).

Even in the face of optimistic manifestations by government authorities, it is surprising that the noise of propaganda is contained in Brazil. In recent years, the initiative has not been widely touted by the media or government propaganda. It seems that the strategy followed is more silent. But the initiatives advance and show the strength of agribusiness, the economic sector that will be most directly benefited by the enterprise. Perhaps it explains the silent nature of the propaganda precisely the fact that the initiative makes clear the role of China in the large commodities market, which determines the redesign of the circuits of transport of goods, including within Brazil. This fact reveals how unfocused is the ideological discourse of the Brazilian government that systematically attacks the main consumer nation of these products. In fairness, it must be said that this is not the position of agribusiness spokespersons, who are also allies of the far-right Brazilian government. Pragmatists, they systematically warn about the need for a balanced conduct of Brazil's foreign policy, especially in relation to China. This is, for example, the case of the minister of agriculture, Tereza Cristina Correa da Costa Dias, another representative of agribusiness in Mato Grosso do Sul.

If, on the economic level, the initiatives around the Bioceanic Route are already visibly taking place, the expectations of many citizens, academic scholars, activists in the environmental issue, defenders of populations most exposed to poverty and threatened cultural practices are that in relation to the environment and culture the things "desaconteçam" ${ }^{5}$. It is opportune to paraphrase Manoel de Barros (1985, p. 33), the poet who coined this expression so appropriate to highlight the paradoxical movement of many initiatives that impacted the Pantanal in the past.

\footnotetext{
${ }^{4}$ Expression that, in the Spanish language, involves a strong sense of belonging, absent, respectively, in the Portuguese and English expressions "Nossa América" and "Our America".

${ }^{5}$ Neologism created by the poet Manoel de Barros. It means that, through the transformation of social relations, something existing loses its original functions. Its use is corrupted, like the cart mentioned by the poet, which, replaced by the tractor, lay forgotten in the backyard of the farm's headquarters. It was falling apart, over time, while its components were pulled out to fulfill the most daring purposes.
} 
In a special issue of the magazine Interações thematically devoted to the Bioceanic Route, an article stressed the need to measure the impacts of this undertaking "to verify its benefits, risks, and damages". For the authors, it would be essential to seek "conciliation between production and social, economic and environmental sustainability to ensure Porto Murtinho socioeconomic balance in the medium and long term" (BENITES et al., 2019, p. 278).

Among the dissonant voices, Ecologia e Ação (ECOA), an environmental NGO, has been warning about the threats generated by the Bioceanic Route, especially environmental degradation. For this entity, emerging economic ventures around this economic corridor may cause risks to fauna, increased deforestation, compromised water quality in the Pantanal rivers, negatively affecting, as a result, tourist fishing and the lives of people connected to it (CAMPOS, 2020).

In the implementation of new port units in the city of Porto Murtinho, there is a visible disregard for the prevention of environmental disturbances caused by natural phenomena, such as the periodic flooding of the waters of the Paraguay River, typical of the Pantanal plain. Extensive areas on the banks of this river and its surroundings had their native vegetation completely removed for the installation of new ports. As a result, the Paraguay River's natural flood regulation capacity was put under threat, accelerating siltation processes, compromising its navigability and the quality of water resources. In Porto Murtinho, even tourism based on wildlife observation and the very quality of life of residents are committed to reducing urban green areas.

Therefore, the expectations that things may stop happening in the Southwest region of Mato Grosso do Sul crossed by the Bioceanic Route are not unfounded. Related facts are reinforced by past experience. The historic dive into the Paraguayan border stops witnesses countless cases of grandiose economic projects based on the exploitation of natural resources, once held by government agencies as promises of regional development, as well as improving the living conditions of the local population. The established oligopolies devoted themselves to the indiscriminate extraction of these resources and violently exploited the local workforce, largely from Paraguay. The stories of the extraction of yerba mate (CENTENO, 2008; ALVES, 2005) and tannin (CORRÊA; CORRÊA, 2009), charqueadas (CORRÊA; CORRÊA, 2010; ALVES, 2005) and fishing tourism are well known (VIOLIN; ALVES, 2017; BENITES et al., 2019). In all cases, what followed was the evasion of capital, the withdrawal of companies when the exploited natural resources became scarce or their exploitation became uneconomical. The resident population was condemned to live among the ruins and rubble of these projects, suffering the penury caused by the material misery that followed.

\section{THE OPTIMISTIC DISCOURSE ON THE BIOCEANIC ROUTE AND UNOPTIMISTIC POSSIBILITIES}

The optimistic discourse, both from government bodies, the media, and even from part of the academic production in Mato Grosso do Sul, has ignored the historical experience and sees the Bioceanic Route as a panacea. The impression conveyed by him is that this runner will necessarily trigger an influx of development throughout its course. Certainly, some trading posts along the route could benefit economically from their favorable geographic locations. Tourism will be intensified in certain places, especially in those that already have some infrastructure to do so. However, such occurrences will not be common to all municipalities crossed by the Bioceanic Route. In the case of Mato Grosso do Sul, hopes that the Southwest region may 
undergo a powerful economic rise that will substantially change everyone's lives may be dashed. The absence of initiatives by the State to prepare the region for the transformations that are to come makes a major contribution to this. This trend is historic and there are no indicators that it could change in the near future.

Some possibilities can be suggested to corroborate this judgment. Two examples are presented. The first takes into account that in the southwest of Mato Grosso do Sul, mainly in Porto Murtinho, the river route that would feed the road axis is understood as an important tentacle for the transport of goods.

There is a concern of local businessmen focused on the modernization of the port structure as a result. Millions of reais have been invested on this front. But those who know the history of river navigation in Mato Grosso and Mato Grosso do Sul are clear about the immense difficulties that have always surrounded the routes used. In the past, even ships with small drafts faced difficulties to navigate due to the shallow depth of the riverbeds of the Pantanal, including the Paraguay River. The strandings were constant.

Especially in the dry season, the duration of the trips was prolonged. The situation doesn't seem to have improved. On the contrary, environmentalists warn of the almost generalized siltation of the Pantanal rivers, also due to agricultural projects located on the plateau, close to the surroundings of the plain. The avulsions intensified (MERCANTE; SANTOS; RODRIGUES, 2012) and the course of the Paraguay River changed in several stretches. The facts confirm the veracity of these advertisements. In 2020, the drought practically made it impossible even to export iron and manganese through the Paraguay River for approximately two months. Shortly before, a television report reported that the drought had caused exports by river to drop $50 \%$ (GOMES [Bom Dia MS], 2020). The government propaganda, in a tone of lamentation, informed that, as early as August 2020, activities in the ports of Ladário, Corumbá and Porto Murtinho were being suspended. Until then the export of iron and manganese had been reduced, since only $70 \%$ of the capacity of the vessels was used to avoid stranding. This automatically represented a 30\% increase in freight. The explanations reiterate that the drought phenomenon is natural and cyclical. The State Government also attributed part of the responsibility for the lack of river navigation to the lack of investments by the Federal Government (BRUNO, 2020). At no time was the possibility that the prolonged drought and the silting up of rivers could have been a result of unbridled anthropic action on the environment. It is important to point out that this situation of discontinuity in river transport makes it irregular and negatively affects the supply of goods, breaking flows and generating losses. 
Figure 2 - Sand banks appear in the bed of the Paraguay River in Porto Murtinho, Oct. 102020

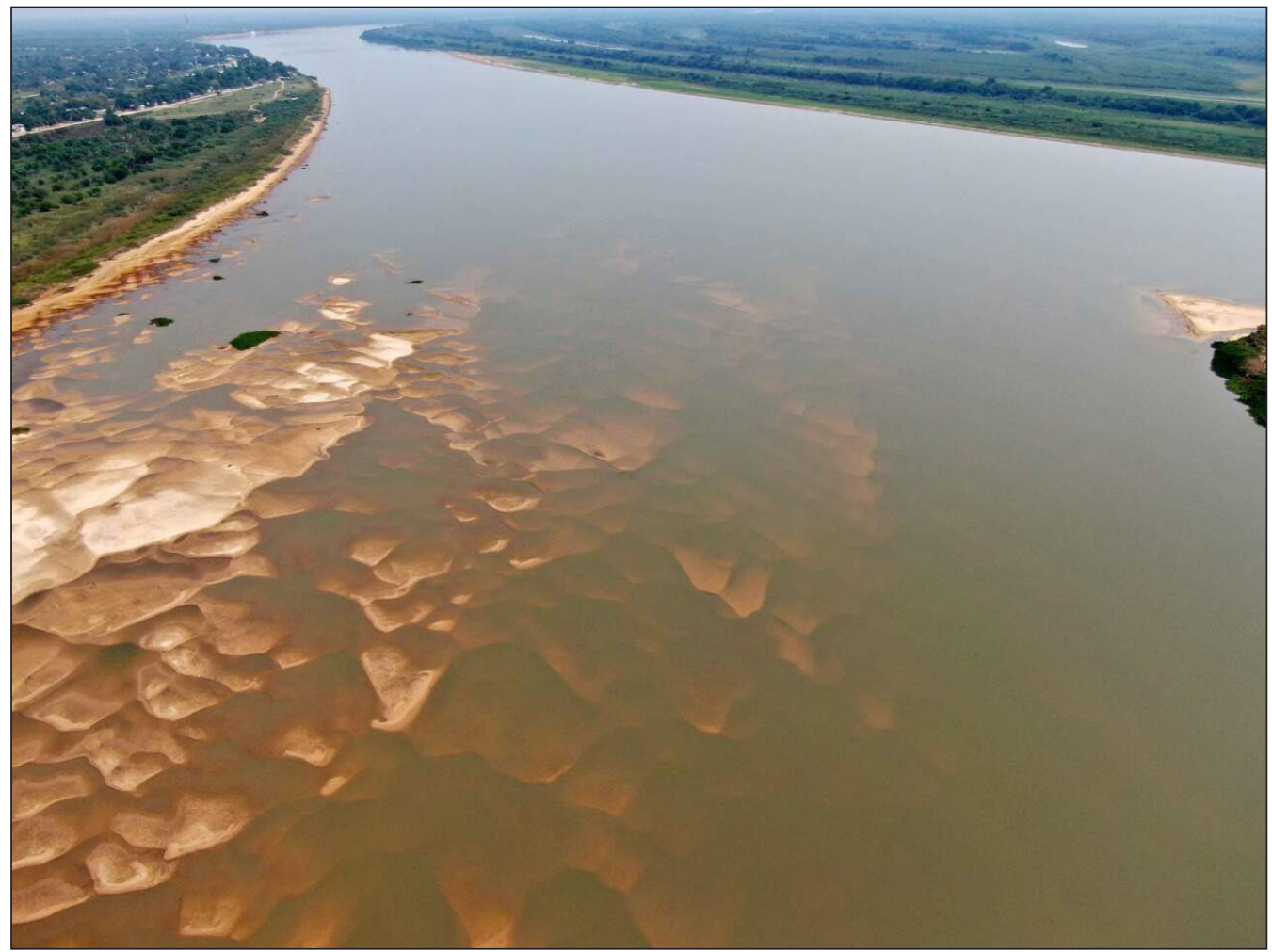

Source: Photos by Toninho Ruiz.

Meanwhile, the highways in Argentina and Paraguay extend towards the great axis of the Bioceanic Route and receive asphalt coating. In Brazil, the route is already fully paved, only needing improvements in some stretches, such as shoulders and third lanes to provide greater safety and agility to the flow of traffic. The construction of the international bridge connecting Porto Murtinho, in Brazil, and Carmelo Peralta, in Paraguay, will be decisive in imposing the full control of road transport, a trend that will free exports from the obstacles and irregularities placed on river navigation. Therefore, this should not have a significant role in the transport of goods in the future. Therefore, the huge damage that may affect local businessmen who are investing heavily in river navigation is looming on the horizon.

The second possibility stems from the fact that the tariff policy in Brazil is quite harmful to commercial ventures established on the country's borders. In all the so-called twin cities, commerce expands on the opposite side (PIRES, 2017). Possibly, this will soon be reproduced for the benefit of Carmelo Peralta, in Paraguay. The trend will not be for Porto Murtinho to place itself at the center of commercial expansion on the border. More likely, in the near future, new commercial establishments will settle in the region, but on the Paraguayan side. It is worth remembering those who already have vast experience with regard to trade in border regions. This is the case, for example, of Shopping China, an oligopoly that has been spreading its units along the borders of Brazil. In the case of Mato Grosso do Sul, in addition to the headquarters in Pedro Juan Caballero (Paraguay), neighboring Ponta Porã, it has another unit in Puerto Aguirre (Bolivia), close to Corumbá (PIRES, 2017). It is possible that Carmelo Peralta, if it develops intensely, will gain a new unit of the company in the coming years. The people 
of Mato Grosso do Sul will have another address abroad to buy drinks, appliances, clothes, perfumes and electronic products.

\section{AN OVERVIEW OF CRAFTS IN MATO GROSSO DO SUL}

To analyze the contribution of handicraft to a strategy for the development of ethnotourism in Mato Grosso do Sul, it is necessary to contextualize this relevant cultural practice in the region. With this intention, when making a preliminary assessment of handicrafts in Mato Grosso do Sul, Alves constructed three categories to classify and describe them. The first, called ancestral crafts, comprises indigenous crafts. As for its fundamental characteristics, it tends to "[...] reiterate, [...], the procedures, techniques, the use of natural resources and the sexual division of labor practiced by previous generations" (ALVES, 2014, p. 48). It is a handicraft linked to the earth and to the immediate environment, as denoted by the raw materials used and the themes explored in the products, systematically referred to the surroundings. The second category, spontaneous crafts, refers to those made by people moved by the inner need to express themselves aesthetically. They pursue beauty, hence the technical refinement, originality, the search for perfection and creativity. They are driven by the pleasure of producing, which in many cases takes on the characteristic of leisure.

With such predicates, they often drift towards artistic making. They are almost always unconcerned about marketing their products at first. But the accumulation of pieces and the knowledge of friends and close people end up helping to publicize the work (ALVES, 2014). Induced crafts correspond to the third category. It has been "[...] an escape valve to remove children and young people who live at risk on the streets or for marginalized populations in poverty ghettos" (ALVES, 2014, p. 48). SEBRAE played an important role in inducing several handicraft experiences throughout Brazil. These experiences were accompanied by the concern to make an ideological conversion of the artisan. He would need to incorporate the notion that crafts cannot be seen as a supplement to income; I would need to see it as an ongoing, professional activity. Finally, to use expressions dear to SEBRAE's proposal, he would need to be aware that handicraft is a business and to predict the scale of production to regularly supply shopkeepers. These would be essential counterparts so that he could embody the desirable figure of the entrepreneur (SERVIÇO BRASILEIRO DE APOIO ÀS MICRO E PEQUENAS EMPRESAS [SEBRAE], 2008).

As a whole, handicrafts in Mato Grosso do Sul have experienced a significant increase since the 1970s. The determining element of this expansion was the organization of tourism in the region. At the beginning of that decade, companies in the sector began to focus their activities on fishing tourism. Combating the destruction of the environment and compromising the fishing stock hindered this activity afterwards. However, in the last decade of the 20th century, ecotourism gained strength in Bonito and Pantanal, generating demands that intensified the flow of tourists and expanded the market for handcrafted products (ALVES, 2016; VIOLIN; ALVES, 2017).

Historical studies showed that handicraft was strangled in the mid-twentieth century. This fact has been recognized, for example, by scholars in the field of anthropology when referring to ancestral craftsmanship (RIBEIRO, 1983; LÉVI-STRAUSS, 1957; OLIVEIRA, 1968; 1976). Production was stagnant. However, with the expansion of tourism in the 1970s, the production of artisanal artifacts was intensified. Indigenous pottery expanded. At the same time and within this favorable framework, many spontaneous artisans, such as Conceição dos Bugres, began placing 
their products on the market (ALVES, 2014). More recently, entities such as SEBRAE, WWF and governments of the federated unit, as well as the main municipalities of Mato Grosso do Sul, started to induce new craft activities. Under the pretext of the need to generate jobs and to remove from poverty large human contingents excluded from the market, these entities started to encourage craft activities that, supposedly, would make use of abundant local raw materials that were not used or reduced to garbage. Sustainability started to be claimed as the central banner to guide the implementation of new encouraged craft modalities (SEBRAE, 2008; WWF-BRASIL, 2011).

Recently, several works have been produced about handicraft in Mato Grosso do Sul. Sometimes describing and synthesizing the craft activities in progress in the State (CENTRO, 2008; PELLEGRINI, 2011), sometimes analyzing the set of craft activities (ALVES, 2014) or deepening the examination of specific experiences (KOMIYAMA, 2014; ALVES, 2017; MARQUES; ALVES, 2019; CANAZILLES, 2013; CANAZILLES; ALVES; MATIAS, 2015; CHAVES, 2019), these works contributed to configure the general framework of this cultural practice in the State.

It deserves to be announced that, in the decade of 2010, many of the induced craft activities began to show difficulties to maintain themselves. Some have already ceased to exist, such as the experience induced by WWF-Brasil in Miranda (WWF-BRASIL, 2011), which imposes the need to discover the determinations of their failure.

In this unbalanced framework, the continuity of ancestral indigenous handicraft reveals strength and promises to be a providential resource to support ethnotourism. But, in parallel, there has been a progressive scrapping of the precarious infrastructure built in the past to boost its sales. Examples are the Terena Culture Referential Center, in Miranda, and the Indigenous Culture Memorial, in Campo Grande, and the market in Porto Murtinho, locally called "Feirinha".

\section{ABOUT ETHNOTOURISM AND THE EXPLOITATION OF INDIGENOUS CRAFT PRODUCTS}

Given the general information needed to contextualize the economic situation generated by the Bioceanic Route and the apprehension of the framework related to artisanal production in Mato Grosso do Sul, it is worth narrowing the script of this study by channeling it towards examining the potential of ethnotourism in the Southwest of Mato Grosso of the South and the role that craftsmanship will play in it.

The discussion about the potential of ethnotourism in Mato Grosso do Sul has been insufficient even in the scope of academic production. This shortage needs to be overcome in the state that has the second-largest indigenous population among the federated units of Brazil. Ethnic groups from the Chaco are mainly established in the Southwest and in neighboring regions, such as the Kadiwéu, the Terena and the Kinikinau. The Kadiwéu reserve is located in the territory of the municipality of Porto Murtinho.

Handicraft thrives in villages located in the Southwest, especially the production of ceramic artifacts. The main pottery center in Kadiwéu is Aldeia Alves de Barros, sixty kilometers away from Bodoquena. Another important production hub is Aldeia São João, seventy kilometers from Bonito, where a population of the Kinikinau ethnic group lives, who are also devoted to handicrafts. In Miranda, very close to the city, several Terena villages are responsible for the production of relevant ethnic handicrafts.

Despite the optimism that marks the discourse on tourism as a result of the Bioceanic Route, it should be stated that the state and municipal governments tend not to do their part in 
developing infrastructure for this purpose. This reckless prediction would be, perhaps, anticipating a result that the facts will be able to disprove in the future. The denial would be welcome, but it supports the forecast, something that has already been raised to the condition of a consistent historical trend in Mato Grosso do Sul. Never have public policies been systematically formulated in order to induce the expansion of tourism. To use an expression widespread in common sense, the State has always followed suit. Everything that was done depended to a great extent on the initiative of private companies linked to the sector. The merit of these companies is acknowledged, but this trend is also fraught with risks.

Therefore, in this field, government promises do not deserve credit, as any political initiatives that have created new alternatives for economic insertion for populations more exposed to poverty or that have contributed to giving them visibility are not counted. Even without the Bioceanic Route, the immense potential of ethnotourism, for example, could already be exploited, but what is observed is the absence and omission of public bodies at the federal, state and municipal levels.

In the context of ethnotourism, what exists, in embryo, is the interest of one or another tourism entrepreneur already aware of its potential. In Miranda this trend is visible. However, entrepreneurs still do not have a clear idea of how to explore and, at the same time, contribute to the solidification of indigenous cultural practices that promise them profits. They do not understand the viable possibility of, through their actions, participating in the promotion of indigenous ethnic groups. In the Terena Cachoeirinha village, during a field survey, a businessman was observed forcing the debasement of the prices of indigenous ceramic pieces to levels far below those practiced by the artisans. In Bonito, shopkeepers try to dissuade tourists from buying indigenous ceramics, claiming that the pieces are low in resistance and poorly painted, according to testimony by a professor at the Federal University of Mato Grosso do Sul. These limitations are also used as arguments by shopkeepers to force prices down when buying indigenous artifacts (CANAZILLES, 2013; CANAZILLES; ALVES; MATIAS, 2015). Entrepreneurs, moved by immediacy, ignore the contribution they could make to the improvement of handicrafts in search of market expansion. Dispossession, a resource to increase profits, reveals unconsciousness of the conditions that could guarantee them greater gains in the future. In short, they are not clear which investments today would boost their profits going forward. Therefore, the commercial relationship they establish with the local indigenous ethnic groups is harmful. A lot of educational work will have to be developed with the entrepreneurs to overcome these obstacles.

Among indigenous leaders and artisans, there is an awareness that it is important to prepare for ethnotourism. As they are unattended by governmental instances and are despoiled by craft traders, with all the difficulties they themselves have been making an immense effort to preserve relevant cultural practices that will become cornerstones for the maturing of ethnotourism in the future. An expressive example is related to ceramic crafts.

A more detailed analysis of the pottery activity among indigenous ethnic groups can clearly illustrate the potentialities and threats surrounding the emergence of ethnotourism. If indigenous ceramics could have great importance in the expansion of tourism in the Southwest region of the state, studies on this object have revealed deficiencies associated with the need to improve products to expand the consumer market (ALVES, 2020). For this to happen, State and municipal support policies will be essential.

The production of indigenous handicrafts, the only form of ancestral handicraft developed in Mato Grosso do Sul, is mainly limited to four indigenous ethnic groups: Kadiwéu, Terena, 
Guarani and Kinikinau. Ceramic pieces dominate. Also, ornamental products that make use of bird feathers, wood, and fibers are common.

In reference works produced in Mato Grosso do Sul, indigenous handicraft is the object of grandiloquent discourse. It is treated, for example, as a sign of "Southern Mato Grosso cultural identity", a cliché that hides the emptiness of content. The information focuses on generalities, such as the formal characteristics of the handcrafted pieces, colors, graphics, techniques and natural products involved in their production (CENTRO, 2008; PELLEGRINI, 2011).

Something systematically ignored refers to the endemic crisis that indigenous handicraft has been going through in Mato Grosso do Sul. Omitting this fact ends up being very convenient for public agencies, as they free themselves from the duty of creating support policies aimed at overcoming limitations very visible today. Without facing this crisis, there is no possibility of exploring ethnotourism in the Southwest of the state.

There are many shortages of indigenous handicrafts. Taking ceramics as an example, the flagship in the artisanal production of the Kadiwéu, Terena and Kinikinau ethnic groups, obstacles that limit both the production and the commercialization of artifacts can be pointed out.

Figure 3 - Indigenous Ceramic Pieces: Kadiwéu (left), Terena (centre) and Kinikinau (right)

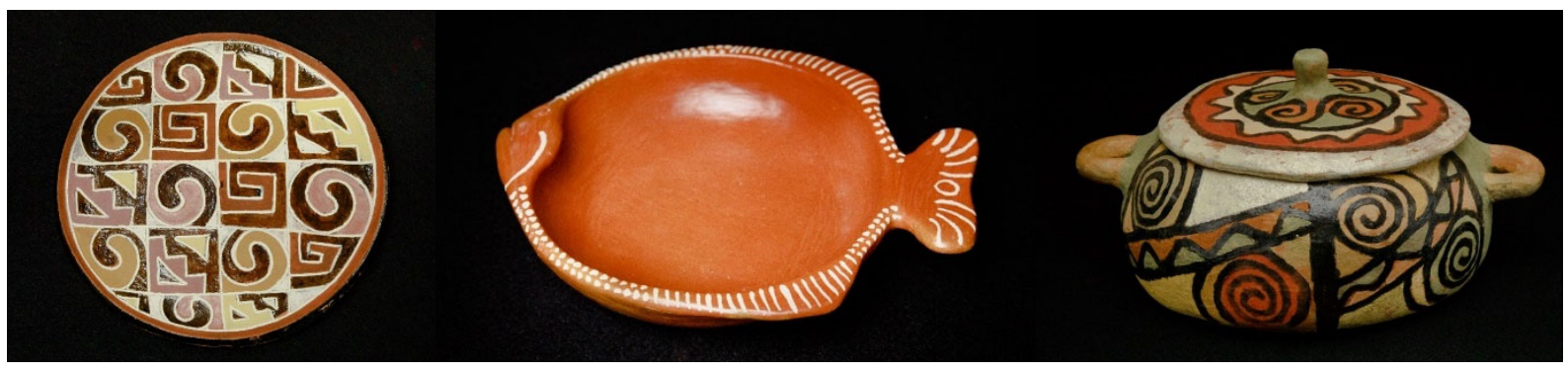

Source: Photos by André Barbosa.

In the case of Kadiwéu ceramics, the change in habitat, imposed by the transfer of villages close to the Paraguay River to the upper Serra da Bodoquena, created a situation that affected the production of ceramic pieces. Before, the pigments used in ornamentation were limited to the black of kingwood, the red of hematite and the ocher of the clay itself. Angico also supplied raw material that could be applied to painting. In the Serra de Bodoquena, on the contrary, colored clay pigments abound. In relation to the old practice, the black of pau-santo and the ocher of the base clay were preserved. The other resources are no longer used. The application of multicolored clays was introduced: green, yellow, red, and brown (RIBEIRO, 1983; ALVES, 2020).

However, if the change resulted in an extensive diversification in the use of colors, the lightening of the painting compromised some results. In the past, the firing took place after the pieces had already been painted. Nowadays, only black people from pau-santo are subjected to this process. The other colors are applied cold, after firing. The result compromises the fixation of colors derived from colored clays. Even the water sprayed on the pieces tends to depigment them (ALVES, 2020).

The burning problem is more complex because, carried out in open fires, the maximum temperature reaches around five hundred degrees centigrade. The pieces have poor strength, therefore. To gain the desirable consistency, it should reach around 900 degrees Fahrenheit (ca. $482^{\circ} \mathrm{C}$ ). Tens and even hundreds of kilometers away from the sales stations, the brittle parts 
suffer great losses both in transport and in handling inside them (CANAZILLES, 2013; ALVES, 2014; 2020; CHAVES, 2015).

These findings highlight the great obstacle faced by indigenous ceramics from Mato Grosso do Sul today. Without projects to support the improvement of production conditions, it is impossible to discuss the expansion of the market for it. Hence, the need for public policies or entities that assume the political commitment to its development. Both the federated unit and the municipalities are silent in the face of the fact and omit.

The situation becomes more critical when considering the threat posed by the compromise of the infrastructure that, in the past, was built to facilitate the sale of handcrafted items from the South Mato Grosso ethnic groups. Examples are the Terena Culture Referential Center, in Miranda, and the Indigenous Culture Memorial, in Campo Grande. The first has been undergoing an evident and progressive destructive process. The second was put in a situation of isolation from the moment it was ignored even by city tour routes in Campo Grande. Still, with regard to the commercialization of indigenous artifacts, the network of artisan houses in the state has also clearly been losing dynamism. This is visible in the Corumbá, Aquidauana and even Campo Grande units, to focus the analysis on the BR 262 axis. The practice of marketing products through the consignment system has made indigenous artisans lose interest in exhibiting their products in these units. In Campo Grande, the artisans offer their artifacts to private craft stores, to their loyal customers and, only then, make the leftovers, when they occur, available to the Casa do Artesão. The consignment sales system is harmful to artisans, as, after financing production, they need an immediate return to guarantee the livelihood of their families and to guarantee the continuity of production. It is also harmful to the Casa do Artesão, which ceases to exhibit the most relevant products of indigenous handicrafts.

In Porto Murtinho, cultural practices involve and integrate Brazilians and Paraguayans. The municipality represents an important service and supply hub that serves Paraguayan populations, especially riverside dwellers and indigenous people from the department of Alto Paraguay. The Paraguay River, at the same time that it separates, is the trunk of interlocutors between Brazilians and Paraguayans. Social relations are markedly "ambivalent" (TEDESCO; ALVES, 2018) in this frontier space.

About the indigenous handicraft sold in the city, it is produced by ethnic groups that live around Carmelo Peralta and Bahía Negra. Raw materials available in the environment are used, such as the fibers of the carandá palm (Copernicia alba) to make household items such as abanicos, brooms, baskets, hats, and bags. Also, noteworthy are the bags made with fibers from the caraguatá plant (Bromelia spp.) by artisans from the Ayoreo ethnic group. Due to its proximity, Porto Murtinho is the main consumer hub. However, the market is shy, as the population did not reach twenty thousand inhabitants and households with monthly income of up to half a minimum wage per person reached $40.4 \%$ of the population at the end of the 2010s (IBGE, 2018). This limitation is also aggravated by the fact that the city does not have the infrastructure for the sale of handcrafted products. 
Figures 4 and 5 - Indigenous handcrafted pieces marketed in Porto Murtinho

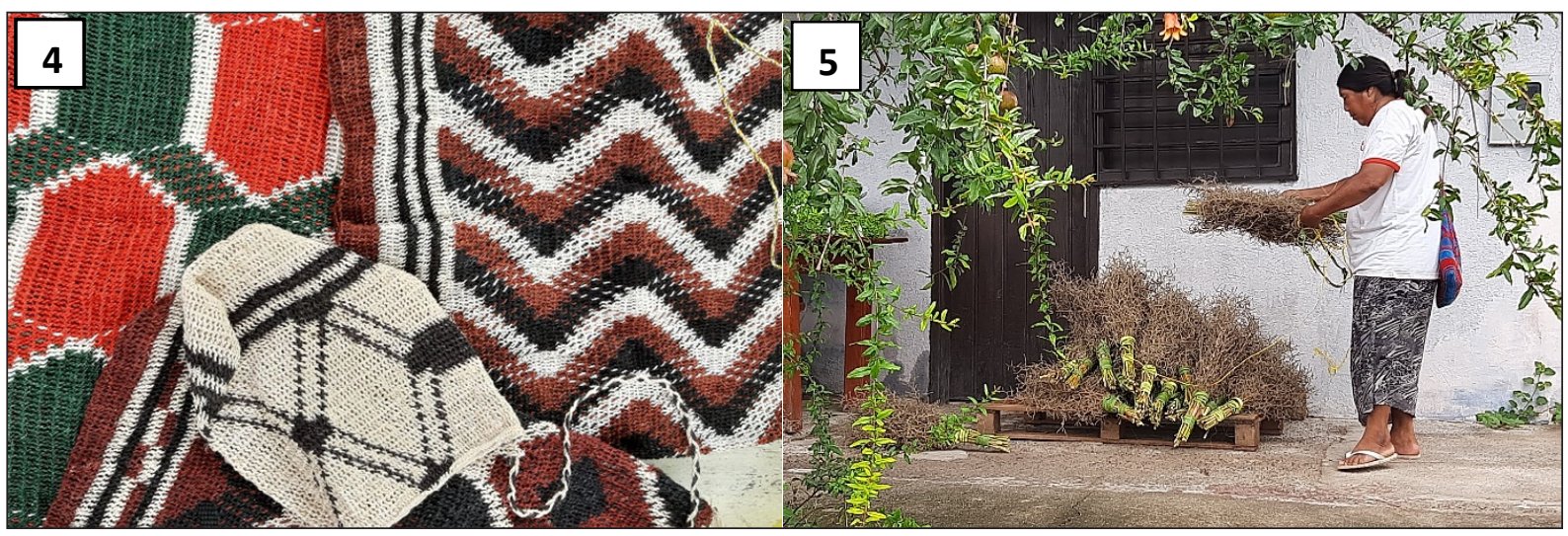

Source: Photos by Maristela Benites.

Historically, the Paraguay River itself has been the spatial reference where exchanges take place. Vessels coming from the surrounding communities transport the goods, such as the Aquidaban boat or small private boats. They are sold at the city's port, on the banks of the river, or are offered by the artisans to merchants and residents. It is common to find indigenous people offering handcrafted products made from the fibers of carandá and caraguatá. Although the Kadiwéu Indigenous Land is located in the municipality of Porto Murtinho, its crafts are not sold in local stores. The access of the villages to the seat of the municipality is not done directly. There are no roads, hence the need for a long detour and traffic through other municipalities such as Bonito and Jardim. The same is true of Kinikinau artifacts.

Until 2019, the center of Porto Murtinho had a precarious infrastructure to accommodate marketers. Eventually, they marketed indigenous handicrafts. In this space, it was possible to find typical dishes from the border cuisine and medicinal herbs traditionally used by Paraguayans and incorporated into the habits of Murtinhenses. However, the space is under renovation and no completion date. In the middle of the pandemic, marketers have no place to display and sell their products.

There is an initiative by the municipal administration that encourages and promotes handicrafts that use fibers from the Carandá palm. It is the Caranday Project, but, still in its infancy, it is hampered by the inexistence of a place to sell the production in Porto Murtinho. Some of its artifacts have participated in handicraft fairs promoted by the state.

Regarding the structures available in indigenous potters' villages in southern Mato Grosso for the exploration of ethnotourism, the best equipped is Aldeia Terena Cachoeirinha. Located about 20 kilometers from Miranda, an asphalted road passes alongside the lands of this ethnic group. Access is complemented by a well-preserved dirt road, approximately 5 kilometers long. The Village is crossed by a large avenue, cut across by less than a dozen streets. The overall look is nice. Its expansion has generated environmental threats that impact the production of handicrafts, especially ceramic handicrafts. The stretching of the streets placed a source of clay practically within the urban perimeter (CHAVES; ALVES; MATIAS, 2019).

However, even the infrastructure of Aldeia Cachoeirinha limits the ethnotourism potential, as it is inadequate to offer services to tourists. In it, a building in ruins, built in 1930 by the Indian Protection Service - SPI, deserves restoration. Other buildings are also in a state of disrepair. These spaces, once restored and revitalized, could gain new functions linked to tourist objectives. 
A sports court constitutes equipment that can be exploited to perform dances, songs, and representations of the typical rituals of the ethnic group. But dependencies would still be needed to display handicrafts, food, sweets, fruits and to meet the needs of tourists.

Figures 6 and 7 - Cachoeirinha Village: Headquarters of the Former Indian Protection Service in ruins and covered shed in a state of decay, 2010

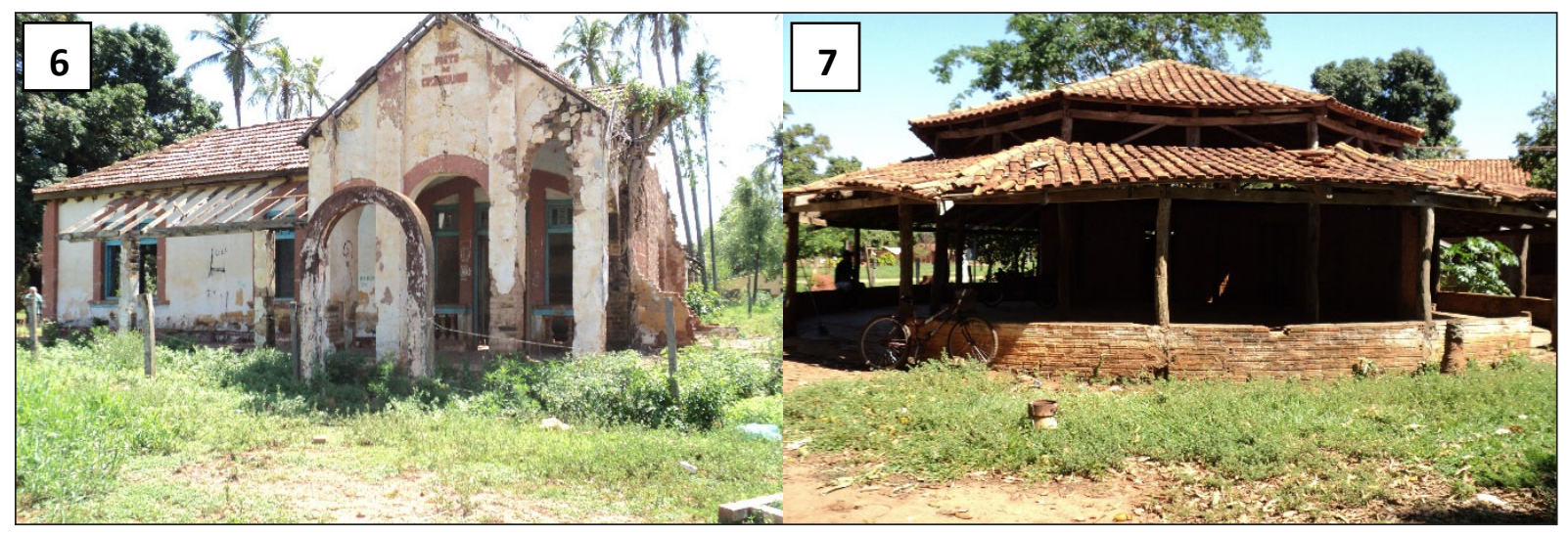

Source: Photos by Gilberto Luiz Alves.

Talking about Aldeia Cachoeirinha, despite the shortcomings pointed out, is, once again, talking about the village that has objective conditions more appropriate to ethnotourism. More difficult is the situation of the Kadiwéu villages. Aldeia Alves de Barros, the main pottery center of the ethnic group, about 60 kilometers away from Bodoquena, is difficult to access due to a rocky road that makes it impossible, in some periods, for small vehicles to circulate. Maintenance is poor and sporadic. The same applies to Aldeia São João, 70 kilometers from Bonito.

As can be deduced, the amount of investment to be applied to improve the conditions that could make ethnotourism viable is not high. Solutions are urgently needed to increase resistance and improve the ornamentation of indigenous artifacts. The restoration and permanent maintenance of roads that give access to the villages are also necessary measures. Buildings can explore techniques traditionally used by the ethnic groups themselves. Some already exist and just need restoration or revitalization. However, to ensure continuity, this set of initiatives must be sought within a project of a permanent nature.

\section{FINAL CONSIDERATIONS}

In summary, it is necessary, once again, to emphasize the conditions that are essential prerequisites for the establishment of ethnotourism in the Southwest region of Mato Grosso do Sul: 1) Efforts must be made, including the support of state universities, to ensure the improvement of services and products likely to be offered by different ethnic groups to tourists; 2) In order to exemplify, in the case of ceramic handicraft, projects that contribute to the improvement of the pieces are needed, from burning to ornamentation, under penalty of making market expansion unfeasible; 3) The villages need to be provided with adequate buildings and spaces for the exercise of all functions associated with ethnotourism; 4) The current spaces and buildings must be evaluated to indicate the appropriate restoration and revitalization measures compatible with ethnotourism; 5) Establish regular traffic conditions on the dirt roads that give 
access to the villages in order to ensure a permanent and continuous flow; 6) Revitalize existing spaces for the commercialization of indigenous handicrafts and encourage the emergence of others, especially in the Southwest region of Mato Grosso do Sul; 7) All these measures and others considered opportune must constitute a permanent execution project.

Finally, it should be noted that optimism about the positive impacts of the implementation of the Bioceanic Route may overshadow the conflicts and challenges faced in the territories affected by this logistical corridor. It can also deceive those who fight and hope for increased appreciation and participation of citizens in decision-making processes, economic insertion and distribution of benefits.

Vigilant attention is needed to combat these mishaps. In the case of academic scholars, the care given to the study and assessment of the cultural and environmental impacts of the economic transformations resulting from the Bioceanic Route, especially in the southwest region of Mato Grosso do Sul, deserves to be redoubled.

\section{REFERENCES}

ALVES, Gilberto Luiz. Utensílio, objeto de arte e mercadoria: a cerâmica indígena em Mato Grosso do Sul. In: ALVES, Gilberto Luiz (Org.). Temas Indígenas Sul-mato-grossenses. Curitiba, PR: Appris, 2020, p. 9-35.

ALVES, Gilberto Luiz. Do "lixo" ao "luxo": o artesanato em osso no município de Jardim, Mato Grosso do Sul. Espacios, Venezuela, v. 38, n. 12, 2017.

ALVES, Gilberto Luiz. O comércio de produtos artesanais e o turismo em Corumbá, Mato Grosso do Sul: 1970-2014. Espacios, Venezuela, v. 37, n. 36, 2016.

ALVES, Gilberto Luiz. Arte, artesanato e desenvolvimento regional: temas sul-mato-grossenses. Campo Grande, MS: Editora UFMS, 2014.

ALVES, Gilberto Luiz. A casa comercial e o capital financeiro em Mato Grosso: 1870-1929. Campo Grande, MS: Editora UNIDERP, 2005.

ALVES, Gilberto Luiz. O pensamento burguês no Seminário de Olinda: 1800-1836. 2. ed. Campo Grande, MS: Editora UFMS; Campinas, SP: Autores Associado, 2001.

ANELO, Marcos. De olho na Rota Bioceânica já tem empresário investindo alto em Porto Murtinho. SBT MS, Campo grande, MS, 13 fev. 2021. Available at: https://youtu.be/4B05RaNM6zc. Access on: 25 Apr. 2021.

BARROS, Manoel. Livro de pré-coisas. Rio de Janeiro: Philobiblion; Campo Grande, MS: Fundação de Cultura de Mato Grosso do Sul, 1985.

BENITES, Maristela; MAMEDE, Simone; CENTENO, Carla Villamaina; ALVES, Gilberto Luiz. Porto Murtinho, Mato Grosso do Sul, e o Corredor Bioceânico: caminhos possíveis para a sustentabilidade socioambiental. Interações, Campo Grande, MS, v. 20, n. especial, p. 267-84, 2019.

BOGGIANI, Guido. Os Caduveo. São Paulo, SP: Livraria Martins Editôra, 1945.

BRUNO, Beatricce. Sem investimentos, hidrovia entra em colapso com seca e reduz exportações. Portal do Governo de Mato Grosso d Sul, Campo Grande, MS, 18 Aug. 2020. Available at: www. $\mathrm{ms}$.gov.br/sem-investimentos-hidrovia-entra-em-colapso-com-a-seca-e-reduz-exportações/. Access on: 24 May 2021. 
CAMPOS, Luana. Rota Bioceânica: o que é e seus impactos diretos e indiretos. Ecologia e Ação-ECOA, Campo Grande, MS, 6 Feb. 2020. Available at: https://ecoa.org.br/rota-bioceanica-o-que-e-e-seusimpactos-diretos-e-indiretos/. Access on: 21 Apr. 2021.

CANAZILLES, Karolinne Sotomayor Azambuja; ALVES, Gilberto Luiz; MATIAS, Rosemary. Comercialização do Artesanato Kinikinau na Cidade Ecoturística de Bonito, Mato Grosso do Sul, Brasil. Pasos - Revista de Turismo e Patrimonio Cultural, v. 13, n. 5, p. 1171-82, 2015.

CANAZILLES, Karolinne Sotomayor Azambuja. A produção e a comercialização do artesanato Kinikinau em Mato Grosso do Sul. 2013. 98 p. Dissertação (Mestrado em Meio Ambiente e Desenvolvimento Regional) - Universidade Anhanguera-Uniderp, Campo Grande, MS, 2013.

CENTENO, Carla Villamaina. Educação e trabalho na fronteira de Mato Grosso: estudo histórico sobre o trabalhador ervateiro (1870-1930). Campo Grande, MS: Editora UFMS, 2008. (Série Fontes Novas)

CHAVES, Francelina Albuquerque; ALVES, Gilberto Luiz; MATIAS, Rosemary. A Produção da Cerâmica Terena na Aldeia Cachoeirinha em Miranda, MS. Revista de Ensino, Educação e Ciências Humanas, Londrina, PR, v. 10, n. 1, p. 73-80, 2019.

CHAVES, Francelina Albuquerque. A produção da cerâmica Terena da Aldeia Cachoeirinha em Miranda, MS. 2015. 94 p. Dissertação (Mestrado em Meio Ambiente e Desenvolvimento Regional) - Universidade Anhanguera-Uniderp, Campo Grande, MS, 2015.

CORRÊA, Valmir Batista; CORRÊA, Lúcia Salsa. Charqueadas: uma alternativa na economia pecuária do sul de Mato Grosso: 1880-1930/40. Albuquerque-Revista de História, Campo Grande, MS, v. 2, n. 3, p. 43-67, Jan./June 2010.

CORRÊA, Valmir Batista; CORRÊA, Lúcia Salsa. O dilema da produção de tanino na fronteira Brasil-Paraguai. Albuquerque - Revista de História, Campo Grande, MS, v. 1, n. 1, p. 55-75, Jan./June 2009.

FUndAÇÃO DE CULTURA DE MATO GROSSO DO SUL [FCMS]. Centro Referencial de Artesanato de Mato Grosso do Sul. Campo Grande, MS: FCMS, 2008. [Catálogo].

GOMES, Cristiano. Estiagem afeta navegação da hidrovia do Rio Paraguai. Bom Dia MS, Campo Grande, MS, 19 Aug. 2020. Available at: https://globoplay.globo.com/v/8788007/. Access on: 24 May 2021.

INSTITUTO BRASILEIRO DE GEOGRAFIA E ESTATÍSTICA. Porto Murtinho. IBGE, Rio de Janeiro, 2018. Available at: https://cidades.ibge.gov.br/brasil/ms/porto-murtinho/panorama. Access on: 18 June 2021.

KOMIYAMA, Cristiane Benevides Pinto. A comercialização de artesanato cerâmico Kadiwéu em Campo Grande, MS. 2014. 57 p. Dissertação (Mestrado em Meio Ambiente e Desenvolvimento Regional) Universidade Anhanguera-Uniderp, Campo Grande, MS, 2014.

LÉVI-STRAUSS, Claude. Tristes Trópicos. Tradução de Wilson Martins. São Paulo: Editôra Anhembi, 1957.

MARQUES, Leila Roque Ribeiro; ALVES, Gilberto Luiz. A produção de artesanato Guarani no município de Dourados, Mato Grosso do Sul. Espaço Ameríndio, Porto Alegre, v. 13, n. 1, p. 198-216, Jan./June 2019.

MERCANTE, Mercedes Abid; SANTOS, Eva Teixeira dos; RODRIGUES, Silvio Carlos. Paisagens do Pantanal Sul-Mato-Grossense: condicionantes e mudanças. In: ALVES, Gilberto Luiz; MERCANTE, Mercedes Abid; FAVERO, Silvio (Orgs.). Pantanal Sul-Mato-Grossense: ameaças e propostas. Campinas, SP: Autores Associados; São Paulo: Universidade Anhanguera-Uniderp, 2012, p. 103-24. 
NOGUEIRA, Elizabete Melo; FERKO, Georgia Patrícia da Silva; COSTA-NETO, Canrobert Penn Lopes; SANTOS, Raimunda Maria Rodrigues; FALCÃO, Márcia Teixeira. Etnoturismo e etnoecologia: possibilidades para o desenvolvimento sustentável em comunidades indígenas. Revista Brasileira de Ecoturismo, São Paulo, v. 6, n. 4 [Anais do $9^{\circ}$ CONECOTUR e do $5^{\circ}$ EcoUC], p. 121-40, 2013.

OLIVEIRA, Roberto Cardoso. Do índio ao bugre: o processo de assimilação dos Terêna. Prefácio de Darcy Ribeiro. Rio de Janeiro, RJ: Francisco Alves, 1976.

OLIVEIRA, Roberto Cardoso. Urbanização e tribalismo: a integração dos índios Terêna numa sociedade de classes. Rio de Janeiro: Zahar Editores, 1968.

PELLEGRINI, Fabio (Org.). Vozes do artesanato. Campo Grande, MS: Fundação de Cultura de Mato Grosso do Sul, 2011.

PIMENTA, Paula. Conferência Rota Bioceânica apresenta discussões sobre oportunidades econômicas e científicas. Portal da Universidade Federal de Mato Grosso do Sul, Campo Grande, MS, 23 July 2019. Available at: https://www.ufms.br/conferencia-rota-bioceanica-apresenta-discussoes-sobreoportunidades-economicas-e-cientificas/. Access on: 25 Apr. 2021.

PIRES, Marco Aurélio Perroni. O Shopping China no desenvolvimento socioeconômico de Ponta Porã/BRe Pedro Juan Caballero/PY. 2017. 86 p. Tese (Doutorado em Meio Ambiente e Desenvolvimento Regional) - Universidade Anhanguera-Uniderp, Campo Grande, MS, 2017.

LESSA, Bruno. Rota Bioceânica: conheça os detalhes do corredor. Portal VGV, [s.I.], 27 June 2020. Available at: https://www.youtube.com/watch?v=crz6sxotHn8. Access on: 25 Apr. 2021.

RIBEIRO, Berta G. Artesanato indígena: para que, para quem? In: RIBEIRO, B. G; ALVIM, M. R. B.; HEYE, A. M.; VIVES, V. de; D’ÁVILA, J. S.; TEIXEIRA, D. L. M. O artesão tradicional e seu papel na sociedade contemporânea. Rio de Janeiro, RJ: FUNARTE / Instituto Nacional do Folclore, 1983. p. 11-28.

RIBEIRO, Darcy. Kadiwéu: ensaios etnológicos sobre o saber, o azar e a beleza. 2. ed. Petrópolis: RJ: Vozes, 1980.

SERVIÇO BRASILEIRO DE APOIO ÀS MICRO E PEQUENAS EMPRESAS. Artesanato - um negócio genuinamente brasileiro. Brasília: SEBRAE, 2008. [Edição comemorativa 10 anos].

TEDESCO, Giselda Paula; ALVES, Gilberto Luiz. Toro Candil: tradição de uma fronteira ambivalente. Interações, Campo Grande, MS, v. 19, n. 1, p. 29-42, Jan./Mar. 2018.

VIOLIN, Fabio Luciano; ALVES, Gilberto Luiz. Da pesca ao natural: trajetória do turismo em Mato Grosso do Sul (1970-2015). Sustentabilidade em Debate, Brasília, DF, v. 8, n. 2, p. 130-46, Aug. 2017.

WWF-BRASIL. Amor-Peixe: modelo de desenvolvimento sustentável. Projeto BR. Brasília, DF: WWF-Brasil, 2011.

\section{About the authors:}

Gilberto Luiz Alves: PhD and Doctorate in Education at the State University of Campinas (UNICAMP). Master's degree in Education at the Federal University of São Carlos (UFScar). Graduated in Pedagogy at the São Paulo State University (UNESP). Professor at the Federal University of Mato Grosso do Sul (UFMS) and professor-researcher at Anhanguera-Uniderp University. E-mail: gilbertoalves9@uol.com.br, Orcid: https://orcid.org/0000-0001-9672-1459 
Fábio Luciano Violin: Doctorate in Environment and Regional Development at the AnhangueraUniderp University. Master's degree in Strategies and Organizations at the Federal University of Paraná (UFPR). Specialist in Strategic Planning and Management at the Pontifical Catholic University of Paraná (PUC-PR). Graduated in Business Administration at the University Centre of the Grande Dourados Region (UNIGRAN). Assistant professor at the São Paulo State University (UNESP), Rosana campus. E-mail: fabio.violin@unesp.br, Orcid: https://orcid.org/0000-0001-9208-3082

Maristela Benites: Doctorate student in Science Teaching at the Federal University of Mato Grosso do Sul (UFMS). Master's degree in Ecology and Preservation, graduated in Biological Sciences, both licentiate and bachelor's degree, at UFMS. Researcher and environmental educator at the Mamede Institute of Environmental Research and Ecotourism. E-mail:mari.benites@gmail.com, Orcid: https://orcid.org/0000-0003-0024-1122 